\title{
Seed system of tef [Eragrostis tef (Zucc.) Trotter] In East Gojjam Zone, Ethiopia
}

\author{
By \\ Melkam Anteneh, Dr. Firew Mekbib
}

Plant Science department, Haramaya University, P.O.Box-138, Dire Dawa-Ethiopia. E-mail: antenehmelkam@yahoo.com. Or firewmekbib@yahoo.com Tel: +251 255530313.

This research was initiated to document Seed System on tef [Eragrostis tef (Zucc.)Trotter]; specifically, quantify the relative importance of formal and farmer tef seed system. A total of 100 sample households drawn from four PAs of the two districts were interviewed using structured interview schedule. Qualitative data were also collected using group discussion among selected tef growers and extension development agents who were working in the respective PAs. The use of appropriate technologies like fertilizer, improved seed, weeding and/or herbicide application with the recommended rate and time helped to increase productivity. Dissemination of improved varieties to farmers is limited. The informal seed system should prioritize improving seed quality by increasing awareness and skills of farmers, improving seed quality of early generations and market access. In conclusion, to enhance tef productivity in east Gojjam zone through supply of improved varieties and quality seed it is important to integrate formal and farmer (informal) seed system.

Key words: Farmer and formal seed system 


\section{INTRODUCTION}

Ethiopian farmers grow tef for a number of merits, which is mainly attributed to the socioeconomic, cultural and agronomic benefits. The area under tef cultivation is over 2,481,333 hectares (ha) of land with annual production of 3,028,018.1ton (t) and yield of 12.2 tons per hectare (t/ha). During the 2008/2009 cropping season, tef occupied 28.29\% of the cultivated land under cereals, while maize occupied $20.16 \%$, sorghum $18.42 \%$, barely $11.148 \%$, finger millet $4.65 \%$, rice $0.4 \%$ and oats $0.35 \%$; this clearly shows the importance of tef in Ethiopia (CSA, 2009).

Nutritionally, tef has as much, or even more food value than the major grains: wheat, barley and maize. This is probably because tef is eaten as the whole grain. Tef grains contains 14-15 percent (\%) proteins, 11-33 milligram (mg) iron, 100-150 $\mathrm{mg}$ calcium and rich with potassium and phosphorous. The absence of anemia in Ethiopia seems to be associated with the level of tef consumption as the grains contain high iron as reported by the US National Academy of Science (1996). Ecologically, tef is adapted to diverse agro-ecological regions of Ethiopia and grows well under stress environments better than other cereals known worldwide (Hailu and Peat, 1996).

Seed is generally considered to be the most affordable external input for farmers, and many of its benefits are assumed to be 'scale-neutral'. So investments in crop improvement potentially can reach a wide range of farmers, while many other inputs such as markets, credit supply, support institutions, policies, and access to appropriate seed also important for agricultural development (McGuire, 2005). The term seed system represents the entire complex organization, individual and institution associated with the development, multiplication, processing, storage, distribution and marketing of seed in any country. The seed system includes informal and the non-traditional (formal or commercial) systems. The formal seed sector was set up and organized with the principal goal of diffusing quality seed of improved varieties developed by formal breeding programs. The principal sources of materials for formal breeding programs are the ex situ collections of gene banks. The farmers' seed production essentially refers to growing a crop for food and save part of it as seed for own use (FAO, 1998). 
Saving the best grains, roots or tubers from consumption, farmer's storage and planting developed over centuries into structured local seed systems. The objective of farmer seed systems is to produce sufficient quantities of seed for the preferred crops and varieties of optimum quality available for each farming unit every planting season (FAO, 1998). This seed system includes various aspects of seed such as production, multiplication and quality control.

Although there is a high demand for tef both in the local and export markets, tef production in Tef seed supply is mostly dominated by the informal seed sector. However, there is little information on informal seed sector, farmers indigenous knowledge in seed selection and maintenance, farmers seed sources, seed quality and seed management practices. Hence this study was undertaken with the following objective: to quantify or evaluate the relative importance of formal and farmer tef seed system

\section{MATERIALS AND METHODS}

\section{Study area}

The study was undertaken in Gozamin and Enarji Enawga district of Eastern Gojjam Zone (EGZ) of Amhara National Regional State (ANRS), Ethiopia (Figure 1). In the study area, during the $2008 / 2009$ cropping season, tef occupied $48.5 \%$ of the cultivated land under cereals, while maize occupied $12.75 \%$, sorghum $6.5 \%$, barely $10.9 \%$, and wheat occupied $20.6 \%$ (CSA, 2009). Gozzamin is near the capital of East Gojjam (Debre Markos) (3-5 km) while Enarji Enawga is $115 \mathrm{~km}$ from Debre Markos. These two weredas were selected based on scale of tef production in the two study areas.

\section{Gozamin district}

The Gozamin district is located at $10^{0} 2^{\prime}-10^{0} 8^{\prime}$ north latitude and $37^{0} 3^{\prime}-38^{0} 1^{\prime}$ east longitudes at about 300 kilometer $(\mathrm{km})$ northwest direction of Addis Ababa. The area receives a mean annual rainfall of $1327 \mathrm{~mm}$ with a mean maximum temperature of $22.4^{\circ} \mathrm{C}$ and a mean minimum temperature of $10.6^{\circ} \mathrm{C}$. The Gozamin district has two Rural Kebele Administration Units 
consisting of 40 peasant associations, 47,199 household farmers and a total human population of 256,974. Over $98 \%$ of the populations of Gozamin have been involved in agriculture. Listed in order of importance, tef, wheat, maize and barely were the dominant crops cultivated in the Gozamin district (GDAO, 2003).

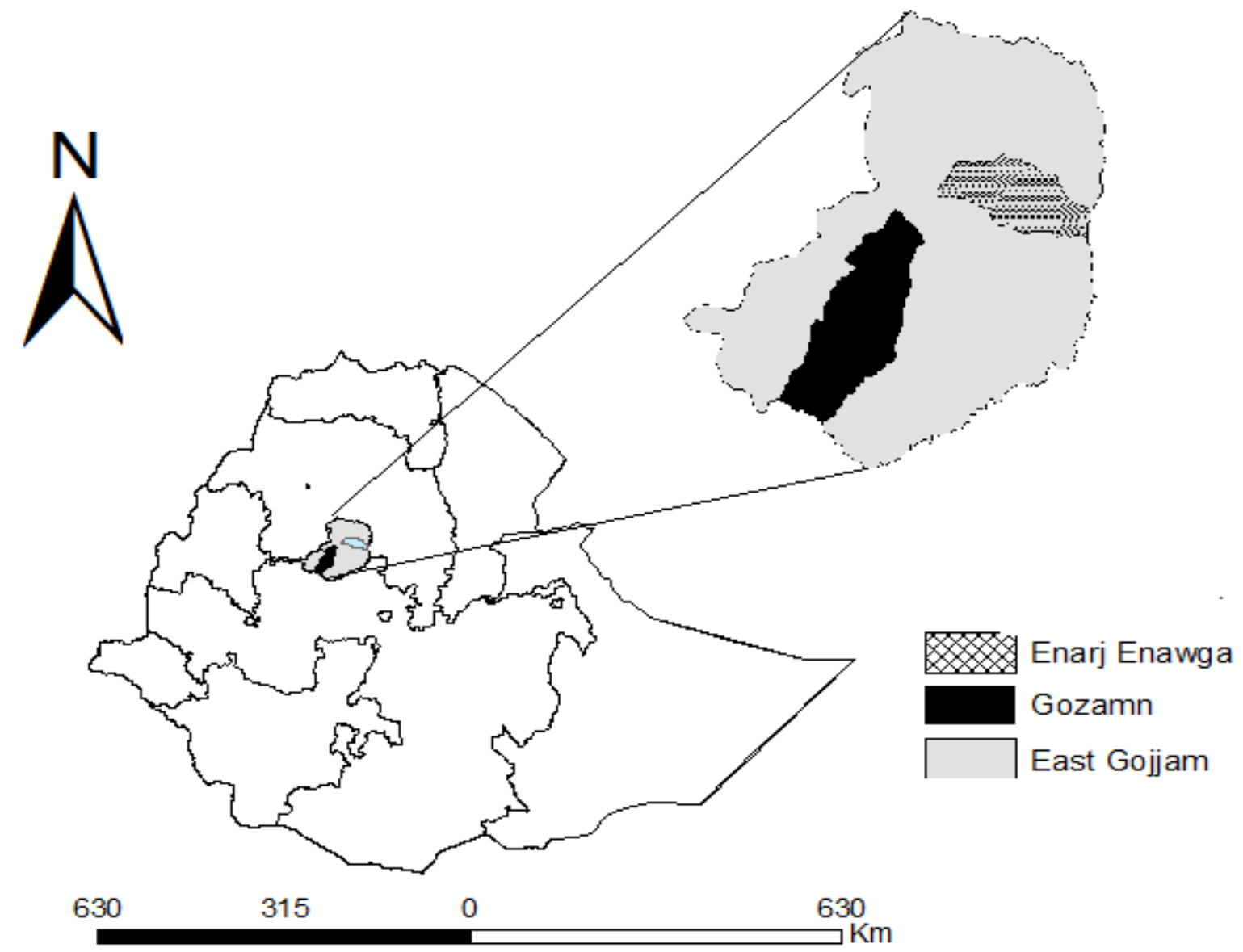

Figure 1. Location map of the study districts

\section{Enarji Enawga district}

The district covers a total land area of 76,095.25 ha with widely varying altitudinal ranges of 1100 to 3200 masl. Accordingly, 30\% of the total land area lies in Dega, 50\% Weynadega and $20 \%$ Kolla. The area receives a mean annual rainfall of $1228 \mathrm{~mm}$ with a mean maximum temperature of $25{ }^{\circ} \mathrm{C}$ and a mean minimum temperature of $7.5^{\circ} \mathrm{C}$. With regards to the land 
features, $50 \%$ of the district is plain with gentle to flat slopes, $30 \%$ is mountainous with undulating to steep slopes and the remaining 20\% constitute valley relief. The Enarji Enawga district rural Kebele administration units consisting of 27 peasant associations has 165,415 household farmers and a total human population of 185,124 . Over $98 \%$ of the populations of Enarji Enawga were involved in agriculture Enarji Enawga District Agricultural office (EEDAO, 2009).

\section{Sampling technique and method of data collection}

Three stage sampling technique used. First, two weredas selected from East Gojjam zone. Second, in each weredas four peasant associations selected purposively. Third, farmers were randomly selected from each peasant association. Formal questionnaires developed and used to collect relevant information from the farmers with the help of trained enumerators. The data collection made in the year 2009/2010. A total of 50 farmers from Gozzamin and 50 from Enarji Enawga interviewed. Additional set of information was collected from relevant governmental organizations to back up questionnaire based statistics. Qualitative data were also collected using group discussion among selected tef growers and extension development agents who were working in the respective PAs.

\section{RESULTS AND DISCUSSION}

\section{Farmer's characteristics and household resource bases in Gozzamin and Enarji Enawga District}

The mean number of male and female family members above 15 years old who helped the farmer during crop production (economically active work force) was 1.48 (SD = 0.68), 1.44 (SD $=0.61$, respectively, the mean number of male and female family member less than 15 years was $2.72(\mathrm{SD}=2.38), 3.44(\mathrm{SD}=2.26)$, respectively, in Gozzamin district. Male and female family member less than 15 years were contributing to farm labor was non-significant $(\mathrm{p}>0.05)$. These findings were roughly similar for both districts. However, male family members greater than 15 years were highly significant different $(\mathrm{p}<0.01)$ between the two districts. Farmers in both districts were sharing labour during plowing, harvesting, and threshing of the tef. 
Furthermore, between the two districts the mean number of cattle and oxen were highly significant $(\mathrm{p}<0.01)($ Table 1$)$.

The average age of household head from sample farmers $(n=100)$ was about 44.8 years $(\mathrm{SD}=$ 12.09) with the range from 28 to over 70 in Gozzamin, $42.76(\mathrm{SD}=7.5)$ with the range from 20 to over 55 in Enarji Enawga district. Only 15\% were over 55 years of age. More than 50\% of the farmers were above the average age indicating less involvement of younger generation in farming. The mean years of farming experience was about 16 years $(\mathrm{SD}=6.45)$ in Gozzamin whereas, 15 years $(\mathrm{SD}=5.33)$ in Enarji Enawga district. Farmers in the two districts were not statistically different in their ages and years of farming experience (Table 1).

Table 1. Family size and livestock number, farmers age, year of farming experience and amount of land allocated in 2009

\begin{tabular}{|c|c|c|c|c|c|}
\hline \multirow[b]{2}{*}{ Item } & \multicolumn{2}{|c|}{ Gozzamin } & \multicolumn{2}{|c|}{ Enarji Enawga } & \multirow[b]{2}{*}{ t-test } \\
\hline & Mean & SD & Mean & SD & \\
\hline Male $>15 y r s$ & 1.48 & 0.68 & 1.96 & 1.05 & $-2.66 * *$ \\
\hline Female $>15 y r s$ & 1.44 & 0.61 & 1.43 & 0.66 & $0.04^{\mathrm{ns}}$ \\
\hline Male $<15$ yrs & 2.72 & 2.38 & 2.22 & 1.29 & $1.27^{\mathrm{ns}}$ \\
\hline Female $<15$ yrs & 3.44 & 2.26 & 2.61 & 1.87 & $1.96^{\mathrm{ns}}$ \\
\hline Number of Cattle & 12.1 & 4.62 & 5.82 & 3.39 & $7.75 * *$ \\
\hline Number of Oxen & 3.52 & 1.432 & 2.0 & 1.29 & $5.57 * *$ \\
\hline Farmers Age & 44.8 & 12.09 & 42.76 & 7.49 & $0.98^{\mathrm{ns}}$ \\
\hline Year of farming experience & 15.9 & 6.45 & 14.86 & 5.33 & $1.07^{\mathrm{ns}}$ \\
\hline \multicolumn{6}{|l|}{ Amount of land allocated 2009} \\
\hline Own land & 2.34 & 0.74 & 1.62 & 0.65 & $5.18 * *$ \\
\hline Hired land & 0.53 & 0.32 & 0.75 & 1.33 & $-3.39 * *$ \\
\hline Share cropped & 0.83 & 0.67 & 1.5 & 0.68 & $-5.01 * *$ \\
\hline
\end{tabular}

About $98 \%$ of farmers had holding rights over the land they cultivated whereas the rest were landless and worked being hired and shared crop land. Farmers $(n=100)$ had previous experience 
having hired (94\% farmers) and shared cropped (90\% farmers) from female headed households or old age or lazy farmers additional land for tef production. The two districts were highly significant different $(\mathrm{p}<0.01)$ in their average size of own land, hired and sharecropped land holding (Table 1).

The household characteristics of the interviewed farmers were almost all male headed one wife but in Enarji Enawga district had only one female headed no husband. Almost all sampled farmers were married, except one (Enarji Enawga districts) who was divorcee (Table 2).

Table 2. House hold type characteristics, educational level of the respondent, position of the respondent and received credit for buying seeds $(\mathrm{n}=50)$

\begin{tabular}{lccccc}
\hline \multirow{2}{*}{ House hold type characteristics' } & \multicolumn{2}{c}{ Gozzamin } & & \multicolumn{2}{c}{ Enarji Enawga } \\
\cline { 2 - 3 } \cline { 5 - 6 } Male headed & $\mathrm{n}$ & $\%$ & & $\mathrm{n}$ & $\%$ \\
Female headed no husband & 50 & 100 & & 49 & 98 \\
\hline Educational level of the respondent & 0 & 0 & & 1 & 2 \\
\hline Illiterate & 32 & 64.0 & & 36 & 72.0 \\
Read and write & 14 & 28.0 & & 11 & 22.0 \\
Elementary school & 3 & 6.0 & & 3 & 6.0 \\
Junior secondary school & 1 & 2.0 & & 0 & 0.0 \\
\hline Position the respondent hold & & & & \\
\hline None & 40 & 80.0 & & 33 & 66.0 \\
PA leadership member & 4 & 8.0 & & 11 & 22.0 \\
Traditional leader & 6 & 12.0 & & 6 & 12.0 \\
\hline Received Credit & & & & \\
\hline Yes & 6 & 12 & & 13 & 26 \\
No & 44 & 88 & & 37 & 74 \\
\hline
\end{tabular}

Source: Own surveyed data, 2010.

The Education level of interviewed farmers varied: 64 and 72\% were illiterate (none), 28 and $22 \%$ can read and write, 6 and $6 \%$ elementary, $2 \%$ and $0 \%$ were Junior secondary school, from 
Gozzamin and Enarji Enawga districts, respectively (Table 2). Farmers with formal education (elementary to high school) constituted $14 \%$, and these would not stay on farm because of employment opportunities in urban area. The social positions of 100 interviewed farmers were 73 of them without position, 15 PA leadership member and 12 farmers were traditional leadership member. Those farmers who have position were more likely to adopt new technology and expand to other farmers or relatives most of the time than those without positions.

Farmers $(38 \%)$ in the sample area received credit from co-operative union, microfinance institute, as a loan from rich farmers rarely from both districts (Table 2). Farmers received credit most of the time for other purposes like construction of house, buy horses and oxen, not used to buy or purchase of tef seed.

\section{Types of crop grown}

The major crops grown includes tef, wheat, maize, and barely. Farmers of EGZ produce various type of crops like millets, oats, sorghum, faba bean, grass pea, nigerseed, chickpea, lentil, Lathyus (guaya), common bean, lupin (gibeto), rapseed, lineseed, sufflower, small amount of sesame dominantly for their own consumption. Crops were listed in Appendix Table 1 with production area in hectares and yield in tons. The productivity of tef was lower than other cereals, for example from the report of BoA of EGZ, 1.68 to 1.99 ton for tef; 2.85 to 4.7 ton for wheat; 1.88 to 2.6 ton for barely; 3.53 to 4.06 ton for maize productivity in the year 2005/2006 to 2009/2010 cropping seasons, respectively. The productivity per unit area of wheat was higher than maize, barely and tef. The area coverage of tef increased from time to time: for example, the total land coverage was 145,129 ha (2005/2006) to 162,394 ha (2009/2010) (Appendix Table 1).

\section{Varieties grown}

\section{Farmer seed system}

Almost all the interviewed farmers had grown tef in both districts. Other local varieties known and grown by most farmers were Daboo (key), Sergenga and Magna (nech) and are normally 
obtained in their own village or travelled no more than $5 \mathrm{~km}$ in search of seed. Farmers' perception on the maturity and threshability of tef varieties was almost all medium. Panicle characteristics were more compacted for Magna tef than Sergenga while Daboo tef panicle loose as compared to the two varieties from both districts. Daboo tef was more susceptible for lodging, rust or pest (red tef worm) than Sergenga and Magna (Table 3).

Table 3. Farmers perception on the currently growing varieties and their characteristics

\begin{tabular}{|c|c|c|c|c|c|c|c|c|c|c|c|c|}
\hline \multirow[b]{3}{*}{ Maturity } & \multicolumn{6}{|c|}{ Gozzamin } & \multicolumn{6}{|c|}{ Enarji Enawga } \\
\hline & \multicolumn{2}{|c|}{ Magna } & \multicolumn{2}{|c|}{ Sergenga } & \multicolumn{2}{|c|}{ Daboo } & \multicolumn{2}{|c|}{ Magna } & \multicolumn{2}{|c|}{ Sergenga } & \multicolumn{2}{|c|}{ Daboo } \\
\hline & $n$ & $\%$ & $n$ & $\%$ & $n$ & $\%$ & $n$ & $\%$ & $n$ & $\%$ & $n$ & $\%$ \\
\hline Early & 2 & 4 & 4 & 8 & 19 & 36 & 21 & 42 & 16 & 32 & 21 & 42 \\
\hline Medium & 28 & 56 & 44 & 88 & 31 & 62 & 27 & 54 & 29 & 58 & 26 & 56 \\
\hline Late & 20 & 40 & 2 & 4 & 1 & 2 & 2 & 4 & 5 & 10 & 1 & 2 \\
\hline \multicolumn{13}{|c|}{$\begin{array}{l}\text { Panicle } \\
\text { characteristics }\end{array}$} \\
\hline Compact & 25 & 50 & 31 & 62 & 15 & 30 & 18 & 36 & 25 & 50 & 3 & 6 \\
\hline Medium & 5 & 10 & 9 & 18 & 13 & 26 & 12 & 24 & 11 & 22 & 9 & 18 \\
\hline Loose & 20 & 40 & 10 & 20 & 22 & 44 & 20 & 40 & 14 & 28 & 38 & 76 \\
\hline \multicolumn{13}{|l|}{ Threshablity } \\
\hline Highly & 2 & 4 & 5 & 10 & 8 & 16 & 16 & 32 & 13 & 26 & 12 & 24 \\
\hline Medium & 38 & 76 & 43 & 86 & 41 & 82 & 29 & 68 & 34 & 68 & 38 & 76 \\
\hline Poorly & 40 & 20 & 2 & 4 & 1 & 2 & 0 & 0 & 3 & 6 & 0 & 0 \\
\hline \multicolumn{13}{|c|}{ Disease or insect } \\
\hline Resistance & & & & & & & & & & & & \\
\hline Resistance & 40 & 80 & 47 & 94 & 39 & 78 & 46 & 92 & 45 & 90 & 35 & 70 \\
\hline Susceptible & 10 & 20 & 3 & 6 & 11 & 22 & 4 & 8 & 5 & 10 & 15 & 30 \\
\hline
\end{tabular}

Source: Own survey data, 2010.

From the discussion, Magna tef seed has pale white color and is the variety favored by all farmers but susceptible to rust and armyworm (Spodotera exempta) like other tef varieties. Daboo (key) tef variety, its selling price was lower, color deep brown, narrow adaptation and it 
had low land coverage in every season production than other tef varieties from both districts. Most of the interviewed farmers did grow (86\%) local Daboo, Magna and Sergenga tef varieties (Table 4). The seed system of farmers was dominantly dependent on the farmers' varieties. This is in agreement with the finding of Mekbib (2006a) on sorghum in eastern Ethiopia.

Daboo (key), Sergenga (mix) and Magna (nech) which were local varieties discovered to have more than one name depending upon the localities they were grown (e.g. instead of Daboo farmers said that Bunegn in low land area). These varieties were normally grown on different soil type. Main advantages of the farmers' varieties were the seed quality they had, the seed was readily available and it was cheaper than the improved tef varieties. According to Delouche (1982), at least $80 \%$ of the seed of the main food crops is produced by the farmers themselves, a figure that is confirmed in other reports and also in this study.

\section{Formal seed system}

Mostly, sixteen of the 100 interviewed farmers used improved varieties recently. In the Gozamin district nine of the 50 interviewed farmers used the currently available commercial varieties. The recommended improved tef variety was Dz-01-354 for farmers of the study area locally called as Global which had a long history to be grown in those areas. Generally $32 \%$ of the farmers used improved tef varieties (Table 4). A remarkable increase was observed year to year in both districts in the use of improved tef varieties. However, since the 2004, the speed and use of new varieties has been accelerated and constitute about 30\% of grain traded (Rubyogo et al., 2007). However, access to improved tef seed was limited in the study area. These are probably due to the limited technologies in the research area and, in fact, lack of institute that takes the responsibility to multiply released tef varieties (Mesfin et al., 2004). Reasons for selection of improved varieties of tef from those interviewed farmers increasingly interested responding to their priority needs to increase productivity (i.e. lodging tolerance) with good marketability or white in color and good cooking/eating qualities (palatability).

Table 4. Farmers using improved tef varieties

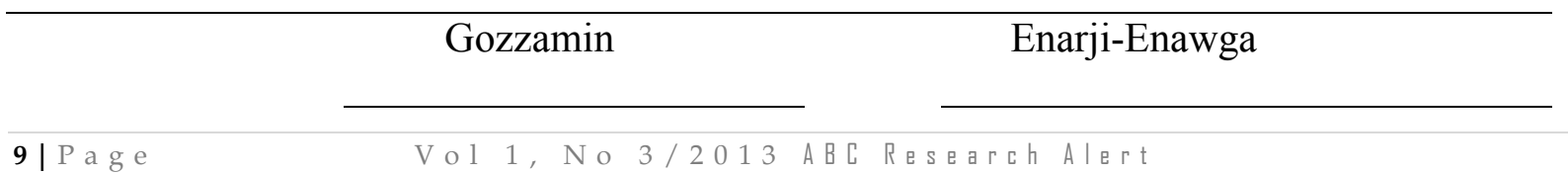




\begin{tabular}{|c|c|c|c|c|}
\hline \multirow[b]{2}{*}{ Farmers using } & & \\
\hline & $\mathrm{n}$ & $\%$ & $\mathrm{n}$ & $\%$ \\
\hline Yes & 9 & 18 & 7 & 14 \\
\hline No & 41 & 82 & 43 & 86 \\
\hline
\end{tabular}

Source: own survey data, 2010.

Extension agents said that, the ESE and Ethiopian Agricultural Research Organization (EARO) used to send limited amount of improved tef seed and distributed to small numbers of farmers with the help of district BoA. From key informant interview ESE is involved in tef seed production of improved varieties like Dz-01-387, Dz-01-974, Dz-cr-37, Dz-01-354 and Dz-01196 at certified level with 3151 hectares of land produced 37,600 quintal in 2008/2009 year. BoA for demand for certified seed was higher than the seed demand forecasted by the ESE marketing division.

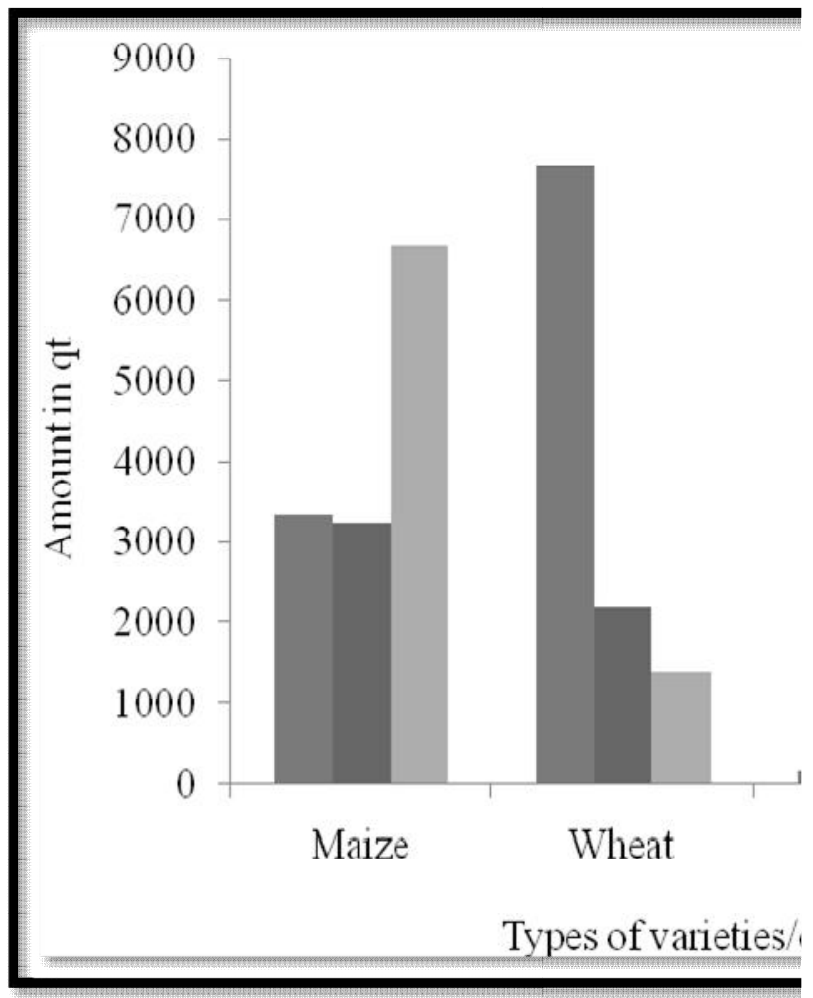

Figure 2. Crop varieties, certified seed supply and distribution (BoAs of EGZ, 2009/10)

BoAs have been aiming to make improved seed available for the small farming communities. As indicated in Figure (2), the supply or demand of certified wheat and maize seed were higher than 
tef seed with three and four varieties respectively in the year 2009/2010. For example, the distribution of certified maize seed were 3247.9 qt (BH 660, BH 540, A 511 and BH 543) and certified wheat were 2187.5 (Har1685, Har604 and Durum wheat) for small scale farmers by EGZ Agricultural Office (Appendix Table 2).

Source of information for improved varieties with packages were radio, district BoAs office, other farmers, relatives and neighbours. Farmers of both districts were not aware of the storage structure from radio and extension agents (Table 5). Across the two districts, farmers depended on relatives for information on new varieties, followed by neighbours. Informal sources of information such as relatives, neighbours and other farmers appeared to be the major sources of information flow compared to the formal extension services.

Table 5. Sources of information about improved tef varieties

\begin{tabular}{|c|c|c|c|c|c|c|c|c|c|c|c|c|}
\hline \multirow{3}{*}{$\begin{array}{l}\text { Source of } \\
\text { information }\end{array}$} & \multicolumn{6}{|c|}{ Gozzamin } & \multicolumn{6}{|c|}{ Enarji Enawga } \\
\hline & \multicolumn{2}{|c|}{$\begin{array}{l}\text { Improved } \\
\text { varieties }\end{array}$} & \multicolumn{2}{|c|}{ Fertilizer } & \multicolumn{2}{|c|}{ Storage } & \multicolumn{2}{|c|}{$\begin{array}{l}\text { Improved } \\
\text { varieties }\end{array}$} & \multicolumn{2}{|c|}{ Fertilizer } & \multicolumn{2}{|c|}{ Storage } \\
\hline & $\mathrm{n}$ & $\%$ & $\mathrm{n}$ & $\%$ & $\mathrm{n}$ & $\%$ & $\mathrm{n}$ & $\%$ & $\mathrm{n}$ & $\%$ & $\mathrm{n}$ & $\%$ \\
\hline Radio & 11 & 22 & 31 & 62 & 0 & 0 & 2 & 4 & 15 & 30 & 0 & 0 \\
\hline DAs & 8 & 16 & 15 & 30 & 0 & 0 & 11 & 22 & 9 & 18 & 0 & 0 \\
\hline Other farmers & 8 & 16 & 0 & 0 & 11 & 22 & 2 & 4 & 4 & 8 & 11 & 22 \\
\hline Relatives & 8 & 16 & 4 & 8 & 25 & 50 & 26 & 52 & 13 & 26 & 18 & 36 \\
\hline Neighbors & 15 & 30 & 0 & 0 & 14 & 28 & 9 & 18 & 9 & 18 & 21 & 42 \\
\hline
\end{tabular}

Source: Own survey data, 2010.

The other farmers who were seed sources had participated in extension agents on farm trials and farmers training. The linkage between organizations such as research, extensions and development was poor in both districts. Although none from Gozzamin and Enarji Enawga districts had access to information about improved tef varieties from the Amhara Regional Agricultural Research Institute (ARARI) as farmers are located far away from institute and no institute research activity is available in the two districts. 
No seed was distributed by the formal sector except the seed made available by BoA through demonstration and popularization programs. These revealed that, the trained farmers (seed/grain producers) took the lead in passing that information to the field day participants (Rubyogo et al., 2007). Tripp and Pal (1998) also found that other farmers followed by shopkeepers were the major sources of information for hybrid pearl millet growers particularly within villages in Rajasthan, India.

\section{Seed sources: initial and current}

Gift (done only initially) followed by exchange had the highest seed standards because it was given from the seed saved for planting. Seed sources of farmers' in 2009 and 2010 cropping season were own saved seed, BoA and exchange with other crop seed (Table 6). So, farmers' seed source of tef was initially as a gift from parents, the later on own stock dominated which is in agreement with the finding of Mekbib (2006b) on sorghum in eastern Ethiopia.

Table 6. Initial sources of tef seed

\begin{tabular}{lcccccc}
\hline \multirow{2}{*}{ Initial Seed Source } & \multicolumn{2}{c}{ Gozzamin } & & \multicolumn{2}{c}{ Enarji Enawga } \\
\cline { 2 - 3 } \cline { 5 - 6 } \cline { 5 - 6 } BoAs & $\mathrm{n}$ & $\%$ & & $\mathrm{n}$ & $\%$ \\
Exchange with other crops seed & 1 & & & 8 & 16 \\
Purchase from farmers & 2 & & & 3 & 6 \\
Loan & 5 & & & 8 & 16 \\
Gift & 25 & 50 & & 5 & 10 \\
\hline
\end{tabular}

Source: own survey data, 2010.

Although about $30 \%$ and $16 \%$ were noted to plant seed obtained from BoA, $10 \%$ and $20 \%$ farmers responded to have the culture of exchanging with other crop seeds like wheat, barley and maize receiving or purchasing tef seeds from their neighbours at the time of the survey from Enarji Enawga and Gozzamin districts, respectively. Farmers who used seed from neighbours suggested the importance of changing their seeds anyway because they assumed that yield decreased when the land and the seed/varieties adapt each other among local tef varieties. 
Farmers indicated that in addition to getting seeds from neighbours they either used their own saved seed or buy commercial seed in the same /other years.

The regional agricultural extension program was going on in many parts of the surveyed areas where farmers were supplied with seeds of improved crop varities and other related inputs as packages. Recently distributed improved variety is Dz-Cr-387 (Quncho) for few farmers in 2010 cropping season. Even if, farmers in Enarji Enawga (40\%) and Gozzamin (70\%) knew about improved tef varieties, they did not have access. In addition to supply of the seeds of new varieties, those farmers were considerable source of skills and knowledge about the variety adaptation and management (Rubyogo et al., 2007).

Table 7. Source of tef seed in 2009 and 2010 cropping season

\begin{tabular}{llllll}
\hline \multirow{2}{*}{$\begin{array}{l}\text { Seed source } \\
2009\end{array}$} & \multicolumn{2}{l}{ Enarji Enawga } & & & \multicolumn{2}{l}{ Gozzamin } \\
\cline { 2 - 3 } \cline { 5 - 6 } & $\mathrm{n}$ & & & $\mathrm{n}$ & $\%$ \\
\hline Own saved & 37 & 74 & & 41 & 82 \\
Neighbors' & 6 & 12 & & 5 & 10 \\
Others & 7 & 14 & & & 8 \\
\hline 2010 & 30 & 60 & & 32 & 64 \\
\hline Own saved & 5 & 10 & & 10 & 20 \\
Neighbors' & 15 & 30 & & 8 & 16 \\
Others & & & & & \\
\hline
\end{tabular}

Source: Own survey data, 2010. Note: others include BoAs, Neighbors include tef seed exchange with farmers

\section{Agronomic package, tef seed management and protection}

The frequencies of the land plowed by oxen ranged from four to ten times depending on the cleanlines of the land. The majority of the farmers plowed seven (26\%) and eight (42\%) times when the land was weedy and it normally starts after harvesting in Gozzamin district (Table 8). The available experimental data generally indicated that the grain yield increases with an increase in number of plowing. However, the necessity of plowing more than three times was not 
apparent at least in vertisol areas of the central highlands. Under farmers practices, tef fields are plowed between two and five times; in most cases more than three times (Fufa et al., 2001).

From Gozzamin (64\%) and Enarji Enawga (58\%) district of the sampled farmers weeded at seedling and vegetative stage, one at young stage and three times at vegetative to flowering. Farmers gave due attention to the management of tef production. However, all farmers practiced broadcasting but not row planting which made difficult to do inter-cultivating such as weeding and maintain appropriate plant population. Some of the recommended practices were not properly managed by sampled households. It was witnessed that no shift in their cropping pattern to replace the long time culture of tef production. Research results have also indicated that drilling in rows did not show significant grain yield advantage over the broadcasting method (Fufa et al., 2001).

Table 8. Farmers weeding and plowing frequency

\begin{tabular}{llllll}
\hline \multirow{2}{*}{ Weeding frequency } & \multicolumn{2}{c}{ Gozzamin } & & \multicolumn{2}{c}{ Enarji-Enawga } \\
\cline { 2 - 3 } \cline { 5 - 6 } One times & $\mathrm{n}$ & $\%$ & & $\mathrm{n}$ & $\%$ \\
Two times & 15 & 30 & & 20 & 40 \\
Three times & 32 & 64 & & 29 & 58 \\
\hline Plowing time & 3 & 6 & 1 & 2 \\
\hline Four times & 0 & 0 & & 4 & 8 \\
Five times & 0 & 0 & 7 & 14 \\
Six times & 6 & 12 & 17 & 34 \\
Seven times & 13 & 26 & 13 & 26 \\
Eight times & 21 & 42 & 10 & 20 \\
Nine times & 7 & 14 & 0 & 0 \\
Ten times & 3 & 6 & 0 & 0 \\
\hline
\end{tabular}

Source: own survey data, 2010.

Mostly adopted and widely used fertilizers are DAP and urea and the rate used varied among different farmers. The mean DAP usage was higher than that of urea in both districts. Seed rate 
applied was higher in Gozzamin than Enarji Enawga districts and was significantly different ( $\mathrm{p}<$ 0.05) (Table 9). Similar to present results the use of high dose of nitrogen fertilizer, for instance, is restricted considerably to increase yield in tef. Up to $100 \mathrm{~kg}$ per ha of DAP should be applied to tef grown on Nitosols. These recommendations corroborate the fact that urea is less effective on acidic soils (Tekalign et al., 2001).

All of the farmers apply fertilizer and compost with or without the recommended rate before and after sowing. From Gozzamin (90\%) and Enarji Enawga (60\%) farmers in the two districts had land of medium fertility, while few farmers in each districts had fertile as well as unfertile land. Most farmers in Enarji Enawga district had tef land with good and poor soil fertility than farmers in Gozzamin districts (Table 9).

Table 9. Seed, fertilizer rate and farmers perception of soil fertility

\begin{tabular}{lcccccc}
\hline \multirow{2}{*}{ Rate kg per ha } & \multicolumn{2}{c}{ Gozzamin } & & \multicolumn{2}{c}{ Enarji Enawga } & \\
\cline { 2 - 3 } \cline { 5 - 6 } & Mean & SD & & Mean & SD & t-test \\
\hline Urea & 27.3 & 19.80 & & 32.9 & 28.4 & $-1.14^{\text {ns }}$ \\
DAP & 89.0 & 15.28 & & 100.0 & 48.7 & $-1.52^{\text {ns }}$ \\
Seed & 36.9 & 8.26 & & 33.2 & 7.6 & $2.33^{*}$ \\
\hline Perception on soil fertility & $\mathrm{n}$ & $\%$ & & $\mathrm{n}$ & $\%$ \\
\hline Good & 5 & 10 & & 7 & 14 \\
Medium & 45 & 90 & & 30 & 60 \\
Poor & 0 & 0 & & 13 & 26 \\
\hline
\end{tabular}

Source: Own survey data, 2010. SD= Standard deviation.

During the group discussion, farmers pointed out that when moisture stress occurs cut-worms appear largely on tef fields. It affected Dz-01-354 more than the local one. Farmers control it culturally by mixing mud and cow dung. Herbicide non-users reported that they didn't use herbicide for the cost reason. Instead of using herbicide they burn crop residue on the field to suppress weed development use family labour. Similarly, the return from herbicide was not attractive even though it's effective in saving labour that would be used for other activities (Teklu et al., 2001). 


\section{Seed production, harvesting and processing}

No separate plot was allocated for tef seed production in both districts; it is normally produced with the grain. The reasons indicated by the farmers were no idea about separate production of the seed, scarcity of land and not easily managed during harvesting, threshing. Farmers who had no idea about separate plot production of the tef seed were $40 \%$ and $34 \%$, not manageable during post harvest management $60 \%$ and $34 \%$, scarcity of land $0 \%$ and $32 \%$ from Gozzamin and Enarji Enawga districts, respectively (Table 10).

Table 10. Farmers' reason for not producing tef seed separately, mechanism of tef seed sorting and knowing physiological maturity time

\begin{tabular}{|c|c|c|c|c|}
\hline \multirow[b]{2}{*}{ Reason for not producing tef seed separately } & \multicolumn{2}{|c|}{ Gozzamin } & \multicolumn{2}{|c|}{ Enarji Enawga } \\
\hline & $\mathrm{n}$ & $\%$ & $\mathrm{n}$ & $\%$ \\
\hline No idea about separate production of seed & 20 & 40 & 17 & 34 \\
\hline Not manageable during post harvest process & 30 & 60 & 17 & 34 \\
\hline Scarcity of land & 0 & 0 & 16 & 32 \\
\hline \multicolumn{5}{|l|}{ Farmers mechanism of tef seed sorting } \\
\hline Cleaning after storage before planting & 21 & 42 & 23 & 46 \\
\hline After threshing, separate grain and seed & 9 & 18 & 8 & 16 \\
\hline After storage, planting without cleaning & 20 & 40 & 19 & 36 \\
\hline \multicolumn{5}{|l|}{ Mechanism of knowing physiological maturity } \\
\hline Change in plant color from green to yellow & 31 & 62 & 37 & 64 \\
\hline Change in plant color and plant drying & 4 & 8 & 0 & 0 \\
\hline All & 15 & 30 & 13 & 26 \\
\hline
\end{tabular}

Source: own survey data, 2010.

Forty two and thirty six percent of the farmers store and clean tef seed before planting, $40 \%$ and $36 \%$ of them sow the tef seed without cleaning and $18 \%$ and $16 \%$ after threshing separate seed and grain before storage in Gozzamin and Enarji Enawga districts, respectively. Farmers separate seed from grain threshing up to storage when the rain damaged the harvested panicle (Table 10). Farmers normally produce tef seed with grain and quality of tef seed not easily controlled.

16|Page Vol 1, No 3/2013 ABCResearch Alert 
Mechanism of physiological maturity time detection of sampled farmers were when $62 \%$ and $64 \%$ change the color of the plant green to yellow, $8 \%$ and $0 \%$ change the plant color and when the plant parts dried, $30 \%$ and $26 \%$ farmers used plant color, plant drying, counting the time from sowing up to harvesting from Gozzamin and Enargi Enawga district, respectively (Table 10). Farmers who stayed for long period after physiological maturity tef panicle shatters by strong wind and unexpected rain which could reduce the yield and quality of seed. During focus group discussion, farmers pointed out that in tef there were not separate production practices of seed and grain. However, farmers differentiate seed from that of grain before sowing.

\section{Contractual seed production}

Farmers produce seed contractually in Gozzamin (14\%) and Enarji Enawga (10\%) districts. Moreover, farmers of Gozzamin (84\%) and Enarji Enawga (42\%) district had demand for Contractual Seed Production (CSP) for the reasons of getting good quality seed, yield/income and to get on time all the recommended inputs (Table 11). Although tef is a strategic crop and grown on $32 \%$ of the cultivated land, seed production of this crop was not attractive to large commercial farmers. As a result, small-scale farmers are now being encouraged by ESE to grow seed of this crop on contract with farmer (Kugbei and Fikru 1997).

In the course of discussion, participating farmers benefited by gaining inputs like tef seed from BoAs, sold the seed for other farmers locally for seed and consumption purpose. Wealth was not an issue in CSP as interested farmers produce by renting land (kiray). Moreover, farmers agree on contractual seed production on the next scaling up on tef seed and other crops. As per the key informant interview, the CSP was legally binding agreement between the cooperatives and the farmer to meet the commitments; the cooperatives must provide seed for initial sowing, provide close supervision and technical backup for the seed plots on the same area (kuta getem), and purchase the seed for cash at an agreed price at a specified time.

Table 11. Farmers practicing contractual seed production

\begin{tabular}{|c|c|c|}
\hline & Gozzamin & Enarji Enawga \\
\hline Had contractual seed production & $\mathrm{n}$ & $\%$ \\
\hline
\end{tabular}




\begin{tabular}{lllll}
\hline Yes & 7 & 14 & 5 & 10 \\
No & 43 & 86 & 45 & 90 \\
\hline Type of crop & & & & \\
\hline Wheat & 8 & 16 & 0 & 0 \\
Maize & 21 & 42 & 30 & 60 \\
Tef & 6 & 12 & 10 & 20 \\
Barely & 0 & 0 & 10 & 20 \\
\hline Like to have contractual seed production & & & & \\
for non-participating farmers & & & & \\
\hline Yes & 42 & 84 & 21 & 42 \\
No & 8 & 16 & 29 & 56 \\
\hline
\end{tabular}

Source: Own survey data, 2010.

The farmers must produce high-quality seed, grow the seed in an area of the farm specified by the responsible technical staff, manage the crop, clean the seed after harvest and deliver it at a specified time. Contract prices were based on estimated yield and production cost. BoAs purchase with higher price than the local market but growers sold tef seed to other farmers for grain/seed purpose as they were not bought by cooperatives' or BoA as per the contract timely.

\section{Seed storage and protection}

Farmers of both Gozzamin and Enarji Enawga district, dominantly (88\%) store seed/grain in Gotta for the following reason: (1) seed is not attacked by pests, (2) when seed is not affected by moisture, (3) for seed that needs to be stored for longer period of time. Those to be used immediately are commonly stored in plastic sacks (8\%) and leather sacks (4\%) (Table 12). All farmers had to save seed from one season to the next and have storage structure to maintain good quality seeds for the next cropping season. As report of table 16, hundred percent of the farmers of Gozzamin and 98\% from Enarji Enawga districts put the seed/grain of tef in the storage. Farmers especially women's are responsible for storage and maintenance of seed.

The interviewed farmers said that storage pest were not a major problem in Gozzamin (54\%) and Enarji Enawga (84\%). About $60 \%$ from both districts of sampled farmers protect tef seed by $18 \mid \mathrm{P}$ a g e 
sunning. Chemical was used only $2 \%$ of the farmers from Gozzamin district when the tef is it attacked by rodents when tef is stored in the sacks (Table 12). In the course of discussion, farmers have revealed that there was no serious storage pest for tef, as result they do not have special protection measures. For protection from rodents' farmers was normally used a cat or rattrap.

The amount of tef seed stored was significantly different among tef varieties from both districts. The amounts of Magna and Sergenga tef sold in the sampled area were not significantly different while the amount of Daboo tef sold was highly significant different $(\mathrm{p}<0.01)$ between the two districts (Table 13).

Table 12. Farmers tef storage structure and protection

\begin{tabular}{|c|c|c|c|c|}
\hline \multirow[b]{2}{*}{ Put in to storage } & \multicolumn{2}{|c|}{ Gozzamin } & \multicolumn{2}{|c|}{ Enarji Enawga } \\
\hline & $\mathrm{n}$ & $\%$ & $\mathrm{n}$ & $\%$ \\
\hline Yes & 50 & 100 & 49 & 98 \\
\hline No & 0 & 0 & 1 & 2 \\
\hline \multicolumn{5}{|c|}{ The storage material of seed/grain } \\
\hline Gota in the house & 44 & 88 & 44 & 88 \\
\hline Sack in the house & 4 & 8 & 4 & 8 \\
\hline Jute or leather sacks & 2 & 4 & 2 & 4 \\
\hline \multicolumn{5}{|c|}{ Measures to be taken from storage pests } \\
\hline Not affected the tef seed & 27 & 54 & 42 & 84 \\
\hline Chemical & 1 & 2 & 0 & 0 \\
\hline Sunning & 22 & 44 & 8 & 16 \\
\hline
\end{tabular}

Source: Own survey data, 2010.

Table 13. Varieties of tef seed stored $(\mathrm{kg})$ and sold $(\mathrm{kg})$ in 2009/2010

\begin{tabular}{|c|c|c|c|c|c|}
\hline \multirow[b]{2}{*}{ Tef seed stored $(\mathrm{kg})$} & \multicolumn{2}{|c|}{ Gozzamin } & \multicolumn{2}{|c|}{ Enarji Enawga } & \multirow[b]{2}{*}{ t-test } \\
\hline & Mean & SD & Mean & SD & \\
\hline Magna & 95 & 45.65 & 78.5 & 34.26 & $2.110 * *$ \\
\hline
\end{tabular}




\begin{tabular}{llllll}
\hline Daboo & 73 & 72.10 & 47.5 & 37.54 & $2.220^{* *}$ \\
Sergenga & 78 & 32.89 & 81.0 & 80.10 & $-0.245^{*}$ \\
\hline Tef seed sold (kg) & & & & & \\
\hline Magna & 726.0 & 449.40 & 846 & 498.25 & $-1.265^{\text {ns }}$ \\
Daboo & 306.0 & 177.75 & 422 & 170.58 & $-3.330^{* *}$ \\
Sergenga & 69.7 & 37.200 & 82.5 & 51.57 & $-1.423^{\text {ns }}$
\end{tabular}

Source: Own survey data, 2010. $\mathrm{SD}=$ Standard deviation, ${ }^{*}=$ Significant at $(\mathrm{P}<0.01),{ }^{*} *=$ highly significant $(\mathrm{P}<0.05)$, $\mathrm{ns}=$ Non-Significant $(\mathrm{P}>0.05)$.

\section{Seed diversity, management and varietal selection criteria}

The number of varieties grown also varied within the sampled farmers. Types of varieties usually grown were Magna (16\%) and (2\%); Sergenga and Magna (20\%) and (36\%); Sergenga and Daboo (14\%) and (6\%); Daboo and Magna (16\%) and (6\%); Sergenga, Daboo and Magna $(24 \%)$ and $(28 \%)$ from Gozzamin and Enarji Enawga districts, respectively. Some farmers practiced growing only one tef variety. Farmers producing Magna (76\%), Daboo (60\%), Sergenga (52\%) from Gozzamin and Magna (52\%), Sergenga (84\%), Daboo (48\%) from Enarji Enawga districts. Farmers growing more than one variety normally produced up to three varieties and these were common scenarios (Table 14).

Farmers reflected that simple variety selection to develop locally adapted varieties that are better fitted to the local environment. Farmers of the surveyed area noted change in the performance of the local cultivars. As to the number of varieties grown farmers rated $20 \%$ and $14 \%$ high, $74 \%$ and $70 \%$ medium finally $6 \%$ and $16 \%$ low in Gozzamin and Enarji Enawga districts, respectively (Table 15).

Table 14. Tef varieties usually grown

\begin{tabular}{lllllll}
\hline \multirow{2}{*}{ Type of varieties usually grown } & \multicolumn{2}{c}{ Gozzamin } & & \multicolumn{2}{c}{ Enarji Enawga } \\
\cline { 2 - 3 } \cline { 5 - 6 } & $\mathrm{n}$ & & & $\mathrm{n}$ & $\%$ \\
\hline Sergenga & 2 & 4 & & 7 & 14 \\
\hline
\end{tabular}




\begin{tabular}{lcccc}
\hline Daboo & 3 & 6 & 4 & 8 \\
Magna & 8 & 16 & 1 & 2 \\
Sergenga and Magna & 10 & 20 & 18 & 36 \\
Sergenga and Daboo & 7 & 14 & 3 & 6 \\
Daboo and Magna & 8 & 16 & 3 & 6 \\
Sergenga, Daboo and Magna & 12 & 24 & 14 & 28 \\
\hline
\end{tabular}

Source: Own survey data, 2010.

Table 15. Change in performance of the local varieties, status of on-farm tef genetic resource and varietal/seed selection criteria

\begin{tabular}{|c|c|c|c|c|}
\hline \multirow[b]{2}{*}{ Change in performance } & \multicolumn{2}{|c|}{ Gozzamin } & \multicolumn{2}{|c|}{ Enarji Enawga } \\
\hline & $\mathrm{n}$ & $\%$ & $\mathrm{n}$ & $\%$ \\
\hline Yes & 28 & 56 & 22 & 44 \\
\hline No & 22 & 44 & 28 & 56 \\
\hline \multicolumn{5}{|l|}{ Number of varieties grown by farmers } \\
\hline High & 10 & 20 & 7 & 14 \\
\hline Medium & 37 & 74 & 35 & 70 \\
\hline Low & 3 & 6 & 8 & 16 \\
\hline \multicolumn{5}{|l|}{ Varietal/seed selection criteria } \\
\hline Non-lodging & 2 & 4 & 1 & 2 \\
\hline Pest resistance (disease, insect) & 5 & 10 & 8 & 16 \\
\hline Seed color/marketability & 24 & 48 & 16 & 32 \\
\hline Food quality or water-to-flour ratio & 17 & 34 & 20 & 40 \\
\hline Straw yield or quality & 2 & 4 & 5 & 10 \\
\hline
\end{tabular}

Source: Own survey data, 2010.

In general, farmers on the sampled area were knowledgeable, skilled and confident on tef genetic resources management activities thereby favoring the conservation and improvement of these materials on-farm. From the discussion, farmers pointed out that, there is no change in number and type of varieties grown. The number of varieties grown by the farmers was rated from medium to high. Farmers of both districts indicated none of tef varieties were lost. 
Farmers practiced varietal or seed selection criteria such as for lodging resistance $4 \%$ and $2 \%$, pest resistance $10 \%$ and $16 \%$, seed color or marketability $48 \%$ and $32 \%$, food quality high waterto-flour ratio $34 \%$ and $40 \%$, straw yield and quality $4 \%$ and 10\% from Gozzamin and Enarji Enawga district, respectively (Table 15). As reported by the key informant, tef seed selection was not based on individual plant observation.

\section{Seed security}

Farmers were seeds secured from Gozzamin (92\%), from Enarji Enawga (84\%) districts, while the rest of them were not secured. The reasons of seed insecurity were selling all out, consumption and post harvest problem (Table 16). Similarly, very commonly in the community, the farmer who is seed secure and insecure is known and hence the insecure farmers go and request the secure ones to get seed. As the tradition of rural settlement in the region is based on their affinity (Mekbib, 2006a), seed flow is strongly facilitated.

Table 16. Seed security and reason for seed insecurity

\begin{tabular}{lccccc}
\hline \multirow{2}{*}{ Seed secured } & \multicolumn{2}{c}{ Gozzamin } & & \multicolumn{2}{c}{ Enarji Enawga } \\
\cline { 2 - 3 } \cline { 5 - 6 } & $\mathrm{n}$ & $\%$ & & $\mathrm{n}$ & $\%$ \\
\hline Yes & 46 & & & 42 & 84 \\
No & 4 & & 8 & 16 \\
\hline Reason for seed insecurity & 13 & 26 & & 6 \\
\hline Selling all-out & 12 & 24 & 6 & 12 \\
Consumption & 25 & 50 & 38 & 76 \\
Post harvest problem & & & & & \\
\hline
\end{tabular}

Source: Own survey data, 2010.

SUMMARY AND CONCLUSION

The EGZ farmers have, for centuries, used their own seed of land races saved from previous crops, or seed obtained from neighbouring farmers, usually in exchange for grain or some other commodity or even in the form of credit to be paid back in kind or cash after harvest for the following reasons; it was accessible, cheap and timely available, varieties well adapted/known 
and adaptive to the farmers conditions/needs. Farmers or producers at village level to produce seed cost-effectively and distribute this within the community.

The majority of (86\%) the farmers in the study area are using local varieties of tef; namely, Sergenga, Daboo and Manga. The popular improved tef variety used by the farmers is Dz-01354. The dominance of one variety of tef is both interesting and worrying. Dz-01-354 is very good variety with many desirable attributes and is widely accepted.

The cooperatives were the main and only source of improved tef seed, while most farmers saved their own seed of tef. There seems to be an effective extension service and farmers are aware of new varieties and modern technologies. The necessary inputs were generally available; the main constraint on the use of inputs such as seed, fertilizer and pesticide were not lack of knowledge, but lack of cash to buy them. The extension service was by far the most popular means of disseminating technical information about improved varieties of tef to farmers in this area. Other means such as the radio, the neighbor, or other farmers played an important part. Research, in particular, did not seem important for communicating information directly to the farmers.

The crop and dirt admixture is easily picked out by hand. No machine can select and clean as that of the manual operation. Seed cleaning focuses on winnowing and sieving. Traditional storage material (gota) is more difficult for molds and insects to get started on and also makes aeration more efficient. Linkages with institutions supplying extension services, complementary inputs, etc. are essential. It is important for formal organizations to provide support for strengthening the seed system which are often weak in these areas.

The efforts being made by the ministry of agriculture and other organization to develop local seed business using farmers' cooperatives needs to be strengthened and scaled up to enhance seed supply system. A major strength in having small-scale seed enterprises at village level was the effective link that could form integration between variety selection, seed multiplication, distribution and use, with all stages involving the participation of the smallholders themselves. 
In general the role of formal seed system in the tef seed system is very low. The farmers' seed system dominated. The efforts being made by the BoA to supply improved tef variety did not commensurate with the demand. Hence, to circumvent the challenges and establish sustainable seed system in EGZ, integrating formal and farmer seed system at variety development, seed production, seed management, seed protection, seed processing and marketing is indispensable.

\section{ACKNOWLEDGMENTS}

I would like to express my heartfelt appreciation and special gratitude to Dr. Firew Mekbib for his critical remarks starting from developing the proposal, with unreserved support, continuous encouragement, consistent guidance and constructive criticisms, visit to my research site, suggestions throughout the research work and in the preparation of the manuscript.

I thank the farmers of East Gojjam for participating and sharing their idea and knowledge on different aspects of seed system. I wish to acknowledge Amhara National Regional State Bureau of Agriculture and Rural Development office (ANRRDO) for giving me the chance to pursue my MSc program at Haramaya University and covering my living expense during the study. I am greatly indebted to the Alliance for Green Revolution in Africa (AGRA) projects for offering me research fund with pocket money and Haramaya University and school of plant sciences for the provision of library, accommodation and other facilities.

\section{REFERENCE}

Central Statistical Authority (CSA), 2009. Area, production and yield of crops for private peasant holdings for Mehar season. Addis Ababa, Ethiopia. 
Delouche, J.C., 1982. Seed quality guidelines for the small farmer. Pp. 26-29. In: Improved seed for the small farmer. Conference proceedings. CIAT (Centro Internacional de Agricultura Tropical), California, Colombia.

Enarji Enawga District Agricultural Office (EEDAO), 2009. Annual report of Agricultural activity, East Gojjam.

Food and Agricultural Organization (FAO), 1998. International workshop on Developing Institutional Agreements and Capacity to Assist Farmers in Disaster Situations to Restore Agricultural Systems and Seed Security activities. In: Proceedings: Seed and Plant Genetic Resources Service Plant Production and Protection Division. 3-5 November, 1998, Rome, Italy.

Fufa Hundera, Tesfa Bogale, Hailu Tefera, kebebew Assefa, Tiruneh Kefyalew, Abera Debelo, and Seyfu Ketema, 2001. Agronomy Resarch in Tef. Pp: 167-176. In: Hailu Tefera, Getachew Belay and Mark Sorrells (eds). Narrowing the Rift-tef Research and development. Proceeding of the International Workshop on Tef genetics and Improvement, 16-19 October 2000. Debre Zeit, Ethiopia.

Gozamin District Agricultural Office (GDAO), 2003. Annual reports of agricultural activities. East Gojjam). Ethiopia.

Hailu Tefera and W.E. Peat, 1996. Evaluation of selection methods for grain yield in the $\mathrm{F}_{2}$ and $\mathrm{F}_{3}$ generations of tef (Eragrastis tef). Ethiopian Journal of Agricultural Science. 15: 20-32.

Kugbei, S. and A. Fikru, 1997. The Injera initiative. Caravan 6: 22-25. ICARDA, Aleppo, Syria.

McGuire, S., 2005. Rethinking seed system analysis and reform for sorghum in Ethiopia, Thesis, Wagenigen University, Netherlands, 293p.

Mekbib, F., 2006. Farmer and formal breeding of sorghum (Sorghum bicolar L. (Moench) in eastern Ethiopia:Implication for integerated plant breeding. Euphytica 152:163-176.

Mesfin Haile, Agajie Tesfaye, Lemlem Aregu, and Eyob Mulat, 2004. Market access versus productivity: the case of Tef, Socio-economics Research Division. Holetta Agricultural Research Center, Ethiopia.

National Academy of Sciences (NAS), 1996. Lost crops of Africa volume 1, Grains. BOSTID, National Research Council. National Academy press. Washington, D.C.

Rubyogo, J.C., L. Sperling and T. Assefa, 2007. A new Approach for facilitating farmers" ${ }^{\text {eccess }}$ to bean seed. LEISA Magazine 23(2): 27-29. 
Tekalign Mammo, Teklu Erkossa and Balesh Tulema, 2001. Soil Fertility and Plant Nutrition research on Tef in Ethiopia. Pp. 199-200. In: Hailu Tefera, Getachew Belay and Mark Sorrels (eds.). Narrowing the Rift. Tef Research and Development. Proceeding of the International Workshop on Tef genetics and Improvement, Debre Zeit, Ethiopia, 16-19 October 2000.

Teklu Tesfaye, Fassile Kelemework, Abera Deressa, Elias Zerfu, Kiflu Bedane and Legesse Dadi, 2001."Tef Technology Transfer and Adoption." Pp: 255-264. Proceedings of the 'International workshop on Tef Genetics and Improvement' Debre Zeit, Ethiopia.

Tripp, R. and S. Pal, 1998. Information exchange in commercial seed markets in Rajasthan. Agricultural Research and Extension Network. Network Paper No. 83. ODI, London, UK. 11p. 
Appendix Table 1. Five years (1997/98-2001/02) annual production area and yield in east Gojjam zone agricultural rural development office

\begin{tabular}{|c|c|c|c|c|c|c|c|c|c|c|}
\hline \multirow[b]{2}{*}{ Crops } & \multicolumn{2}{|c|}{$1997 / 98$} & \multicolumn{2}{|c|}{ 1998/99 } & \multicolumn{2}{|c|}{ 1999/2000 } & \multicolumn{2}{|c|}{$2000 / 2001$} & \multicolumn{2}{|c|}{$2001 / 2002$} \\
\hline & Area (ha) & $\begin{array}{l}\text { Production } \\
\text { (tons) }\end{array}$ & Area(ha) & $\begin{array}{l}\text { Production } \\
\text { (tons) }\end{array}$ & Area(ha) & $\begin{array}{l}\text { Production } \\
\text { (tons) }\end{array}$ & Area(ha) & $\begin{array}{l}\text { Production } \\
\text { (tons) }\end{array}$ & Area(ha) & $\begin{array}{l}\text { Production } \\
\text { (tons) }\end{array}$ \\
\hline Tef & 145,129 & $243,743.8$ & 146,578 & $246,680.8$ & 149,056 & $278,969.9$ & 150,788 & $279,448.9$ & 162,394 & 323,462 \\
\hline Wheat & 91,604 & 260,830 & 100,254 & 311,348 & 98,396 & $322,273.7$ & 109,710 & $373,429.2$ & 129,655 & $611,767.8$ \\
\hline Barely & 41,266 & $77,942.1$ & 34,846 & $71,603.5$ & 33,305 & $75,600.1$ & 46,113 & $10,192.2$ & 53,433 & $136,549.3$ \\
\hline Maize & 38,949 & $137,727.1$ & 52,034 & $236,328.4$ & 55,535 & $269,698.8$ & 58,978 & $287,675.5$ & 41,563 & $168,802.2$ \\
\hline Sorghum & 23,868 & $50,465.5$ & 25,428 & $65,872.3$ & 25,567 & $68,830.4$ & 24,264 & 66,768 & 18,423 & $43,162.5$ \\
\hline Bean & 21,942 & $28,997.1$ & 22,546 & $39,413.6$ & 21,426 & $42,315.7$ & 30,161 & $58,502.8$ & 30,125 & 63,095 \\
\hline Pea & 11,904 & $10,827.4$ & 13,926 & $19,645.7$ & 13,286 & $19,792.5$ & 13,513 & $20,280.7$ & 13,993 & $23,560.9$ \\
\hline Lentil & 1,115 & 8,887 & 116 & 9,410 & 1,128 & $9,682.00$ & 1,383 & 11,441 & 843 & 8,502 \\
\hline Chickpea & 9,900 & 15,882 & 10,642 & $19,690.5$ & 9,163 & $19,820.6$ & 11,132 & $23,525.6$ & 9,465 & $22,378.7$ \\
\hline $\operatorname{Vetch}($ guaya $)$ & $1,099.4$ & $1,772.17$ & 963.2 & $1,555.17$ & 1.022 .0 & 2.259 .49 & 1.018 .6 & $2,320.37$ & $1,060.8$ & $2,380.58$ \\
\hline Hortic.crops & - & - & 13,731 & 15,9615 & 16,493 & $18,2075.7$ & 25,014 & 33,6715 & 13,015 & 16,85180 \\
\hline Oat & 10,994 & $17,721.7$ & 9,632 & $15,551.7$ & 10,220 & $22,594.9$ & 10,186 & $23,203.7$ & 10,608 & $23,805.8$ \\
\hline Lupin(Gebeto) & 155 & 1,670 & 244 & 2,938 & 203 & $1,872.00$ & 255 & 2,665 & 15 & 180 \\
\hline
\end{tabular}

Source: East Gojjam Agricultural and Rural Development Office. 
Appendix Table 2. Crop varieties and certified seed distribution by BoAs of EGZ, Ethiopia.

\begin{tabular}{|c|c|c|c|c|c|}
\hline \multirow[t]{2}{*}{ Crops } & \multirow[t]{2}{*}{ Varieties } & \multirow{2}{*}{$\begin{array}{l}\text { Supply (qt) } \\
2009 / 10\end{array}$} & \multirow{2}{*}{$\begin{array}{l}\text { Distribution } \\
(\mathrm{qt})\end{array}$} & \multicolumn{2}{|r|}{ Supply } \\
\hline & & & & $2009 / 10$ & (qt) $2010 / 11$ \\
\hline \multirow[t]{5}{*}{ Maize } & ВH660 & 2832 & 2806 & & 4634 \\
\hline & BH540 & 420 & 412.8 & & 1209 \\
\hline & A511 & 97 & 29.5 & & - \\
\hline & BH543 & - & - & & 832 \\
\hline & Total & 3349 & 3247.9 & & 6675 \\
\hline \multirow[t]{4}{*}{ Wheat } & 1685 & 7241.5 & 2055.76 & & 1400 \\
\hline & 604 & 420 & 68 & & - \\
\hline & Durum Wheat & - & 63.74 & & - \\
\hline & Total & 7662 & 2187.5 & & 1400 \\
\hline \multirow[t]{5}{*}{ Barely } & HB42 & 35 & - & & - \\
\hline & Beca & 50 & - & & - \\
\hline & Shegi & - & - & & 126 \\
\hline & Hollker & 89 & 4.87 & & 125 \\
\hline & Total & 174 & 4.87 & & 251 \\
\hline \multirow[t]{2}{*}{ Bean } & $\mathrm{S} 20$ & - & - & & 33 \\
\hline & Cs20Dk & - & - & & 400 \\
\hline \multirow[t]{3}{*}{ Tef } & Dz-01-354 & 80 & 45 & & 400 \\
\hline & Dz-01-387 & - & - & & 450 \\
\hline & Total & 80 & 45 & & 950 \\
\hline Pea & Tegenech & - & - & & 34 \\
\hline
\end{tabular}

Source: East Gojjam Zone Agricultural and Rural development Office annual report. 